\title{
Physicochemical Characteristics of Corriente River, Argentine, Period 1998-2014
}

\section{Juan Daniel Ruiz Díaz, Diana Corina Fechner, Roxana María Itatí Goyechea, Ramón Alberto Martínez, Francisco Antonio Vazquez}

Laboratorio de Química Ambiental (LABQUIAM), Facultad de Ciencias Exactas y Naturales y Agrimensura, Universidad Nacional del Nordeste, Corrientes, Argentina

Email: fechnerdiana@gmail.com

How to cite this paper: Díaz, J.D.R., Fechner, D.C., Goyechea, R.M.I., Martínez, R.A. and Vazquez, F.A. (2016) Physicochemical Characteristics of Corriente River, Argentine, Period 1998-2014. Journal of Geoscience and Environment Protection, 4, 118125 .

http://dx.doi.org/10.4236/gep.2016.412009

Received: September 19, 2016

Accepted: December 13, 2016

Published: December 16, 2016

Copyright $\odot 2016$ by authors and Scientific Research Publishing Inc.

This work is licensed under the Creative Commons Attribution International

License (CC BY 4.0).

http://creativecommons.org/licenses/by/4.0/

\begin{abstract}
Corriente River is part of the middle Parana basin and it is an inland river of the Corrientes Province of Argentine. This paper studies variation in time of some physicochemical parameters (conductivity, alkalinity, hardness, sulfates and chlorides) measured between 1998 and 2014. The correlations of the data correspond to three fixed stations monitoring. The analysis of results takes into account the influence of the seasonal rainfall patterns regimes as determinants in the natural composition of the water resources studied. Moreover composition of the river has been registered as a valid reference to predict probable changes by human activity.
\end{abstract}

\section{Keywords \\ Composition, Water Resource, Characterization, Evolution}

\section{Introduction}

Water is a vital element and plays an extremely important role for human being, socioeconomic development and the existence of ecosystems [1]. Currently, water is considered as an emergency resource. Thus, the quantity and quality of water supply systems must be followed in order to prevent its pollution.

The Corrientes Province is located in Argentinian Northeastern. It is surrounded by two large courses of fresh water: the Paraná and the Uruguay rivers. The Corriente River is born in Ibera System and crosses the province towards the southwest. The major area of the province is used by forestation, agricultural and cattle raising activities. Agricultural activity (mainly rice farms) grows up faster than urban areas and industrial activities. In consequence, water disturbs must be managed in a sustainable manner. Then, it is necessary to know the natural variations of water resources. Therefore it is 
necessary to have reliable references regarding the normal variations of its composition as a result of the rainfall regime, in order to detect alterations due to anthropic activities.

Water resources of Corrientes-Argentine are controlled by provincial and national governmental entities: Instituto Correntino del Agua y del Ambiente (ICAA) and Secretaría de Recursos Hídricos de la Nación Argentina, respectively. Water quality monitoring is an important tool of environmental monitoring under the ICAA management. Water quality monitoring has been carried out for many years throughout the Corriente river basin by the Laboratorio de QuímicaAmbiental (LABQUIAM).

Water quality issues may be very important at a local level and involving streams and other water bodies. These local issues may have a large impact on the safe water supply for human consumption and other uses, fisheries and other aspects on the environment. The most effective way to identify and deal with water body problems may be through watershed planning and management; it is therefore essential to know the historical nature of the resource.

There is a lot of information around the world showing surface waters characteristics, and their influences on managements [2]-[10], including rivers of Argentina. Related to this topic, the LABQUIAM reports that over the last two decades of monitoring water quality of Paraná and Uruguay rivers has been good and it is not affected significantly by human activities [11] [12]. In advance, we studied the water body of another river which was not reported before. Now, this paper presents temporal variations of five physical-chemical parameters and their relationships in three sampling sites, comparing data of year 1998, 1999, 2011-2014.

\section{Methods}

\subsection{Study Site}

The Corriente River is born in Laguna Itatí and collect great amount of water of the lagoons (great areas under water with very little depth, between 0 - 1 meters) functions as drainage of the wetlands Iberá system $\left(13,000 \mathrm{~km}^{2}\right)$. Furthermore, the power supply source is rainwater, with some probability of groundwater supply. The speed of movement of Corriente River is low, as a typical river of plain. Almost all the channel extension is encased in a little deep. It travels around about 400 kilometers from northwest to southwest in the Corrientes Province, emptying at the Paraná River, in Esquina city. The climate of the region where it is located is tropical with rains all the year but that is strengthened during the spring-summer, surpassing the average values. The rainfall regime is not constant over the years and sometimes widely exceeds traditional means. On these occasions the river overflows and remains out of its normal course for months.

\subsection{Samples}

The water sampling sites (Figure 1) were selected from a well-studied reconnaissance land. Samples were collected from 3 sampling stations localized using a GARMIN Geo- 
graphic Positioning System (GPS) device:

1) Paso Lucero: $S 28^{\circ} 59^{\prime} 39.5^{\prime \prime}$; W $58^{\circ} 33^{\prime} 32.3^{\prime \prime}$

2) Paso López: $S 29^{\circ} 13^{\prime} 25^{\prime \prime}$; W $58^{\circ} 46^{\prime} 38.5^{\prime \prime}$

3) Paso Santa Rosa: $S 29^{\circ} 48^{\prime} 38.5^{\prime \prime}$; W $59^{\circ} 23^{\prime} 35.7^{\prime \prime}$

Samples were collected from the midstream of the river following the guidelines of standard methods [13]. Fresh surface waters (from a depth of $05 \mathrm{~m}$ ) was collected three time a year from each site over along 1998-1999-2011-2012-2013 and 2014 year, using 1 L polypropylene sampling bottles. The water samples were transferred in a portable refrigerator at $4^{\circ} \mathrm{C}$ to the laboratory. The sampling program provided on a seasonal basis measurements of the physicochemical parameters of the river waters

\subsection{Physicochemical Analysis}

The physicochemical parameters monitored are: color, turbidity, conductivity, $\mathrm{pH}$, total residue, chlorides, alkalinity, sulfates, nitrogen series, dissolved oxygen, COD, hardness, calcium, iron and phosphate. The chemical analyses were carried out using APHA Standard Methods [13]. The parameters reported in this occasion are the most influenced by dilution: conductivity, chlorides, alkalinity, hardness and sulfates.

The determinations were performed at the Environmental Chemistry Laboratory (LABQUIAM) of the Faculty of Natural Sciences and Surveying, Northeastern University, Corrientes, Argentina.

\section{Results}

The average values (three sampling from each sampling sites per year) from the results of samples in different monitoring sites are showed in Figures 2-6.

And the maximum and minimum values obtained throughout the study period can be viewed in the following Table 1, being evident the marked difference between extreme values:

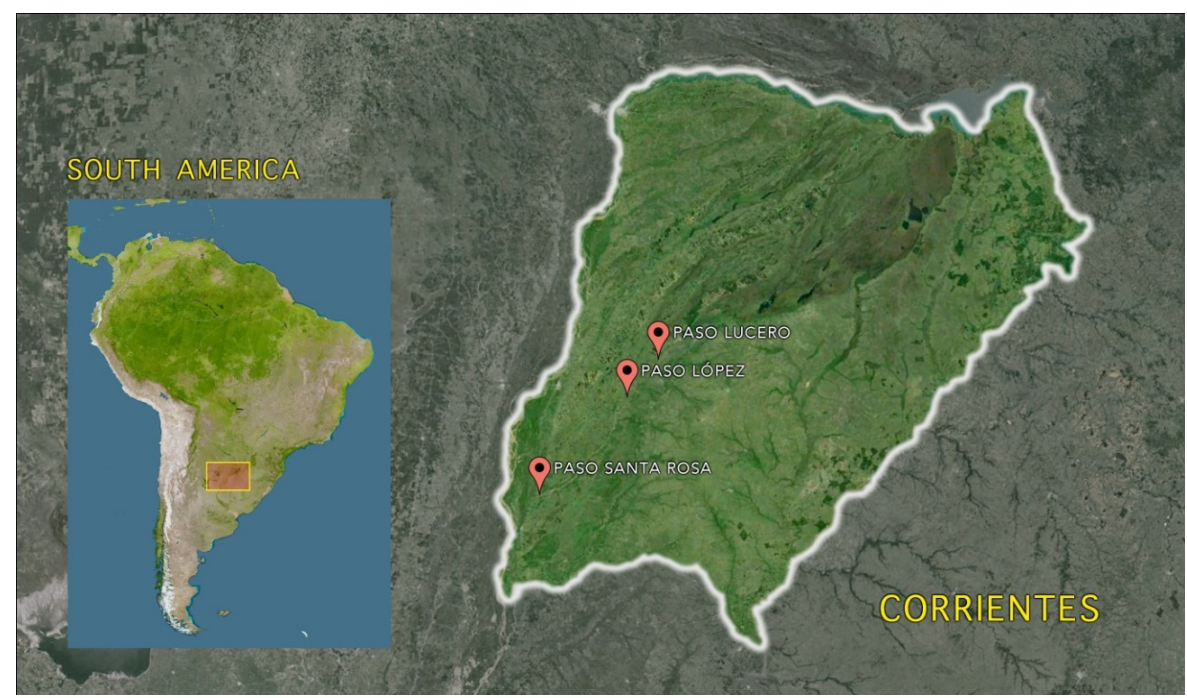

Figure 1. Sampling sites of Corriente River. 


\section{Conductivity}

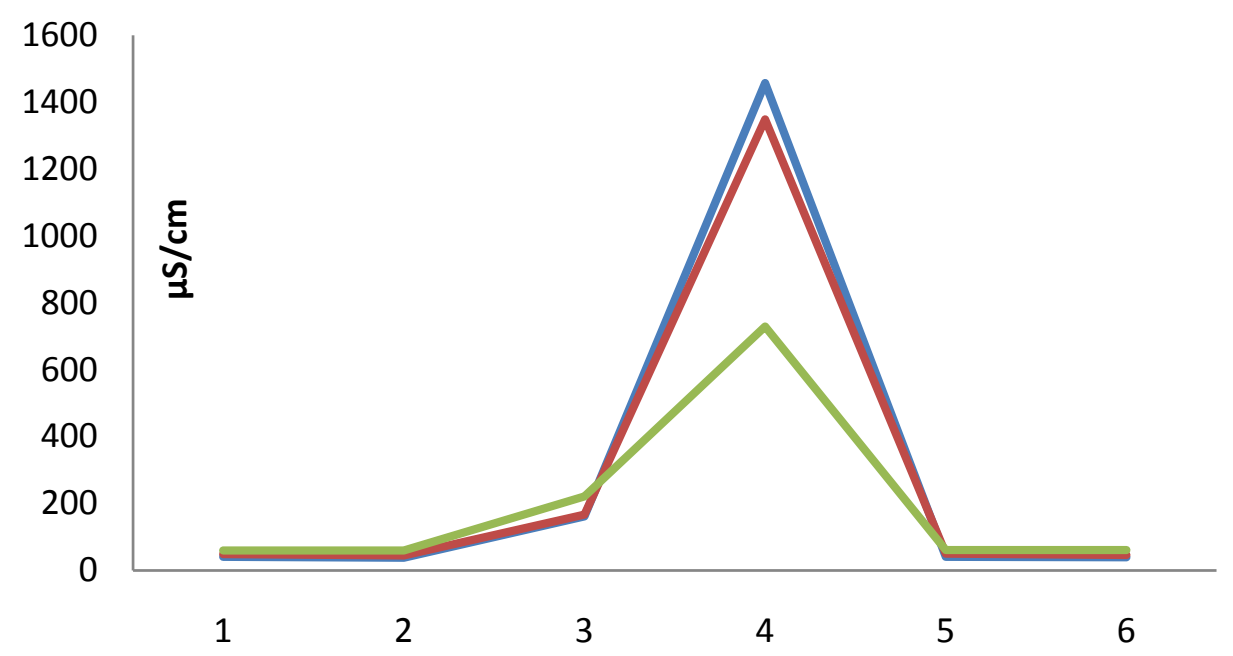

Figure 2. Conductivity average (three sampling per year) in 1998 (1), 1999 (2), 2011 (3), 2012 (4), 2013 (5), 2014 (6).

\section{Chlorides}

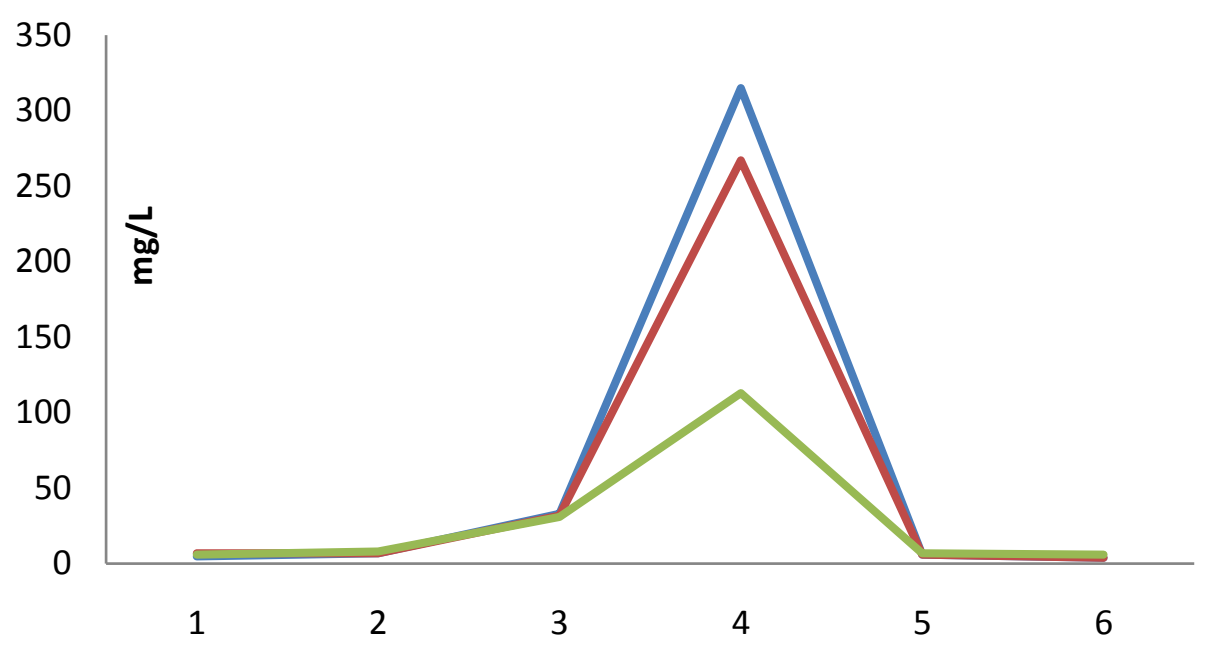

Figure 3. Chlorides average (three sampling per year) in 1998 (1), 1999 (2), 2011 (3), 2012 (4), 2013 (5), 2014 (6).

According to data obtained from the website of ICAA, in 2012 there was a very large variation in rainfall in the area. The records show a marked decline in rainfall of 2012:

Total recorded rainfall for the last studied years is: 2010: $1649 \mathrm{~mm} ; 2011: 1439 \mathrm{~mm}$; 2012: $1046 \mathrm{~mm}$; 2013: $1564 \mathrm{~mm}$; 2014: $1343 \mathrm{~mm}$.

\section{Discussion}

As mentioned in Methods section, indicator parameters of dilution variations have been selected on this occasion. They are very easy to determine and accessible to any 
Alkalinity

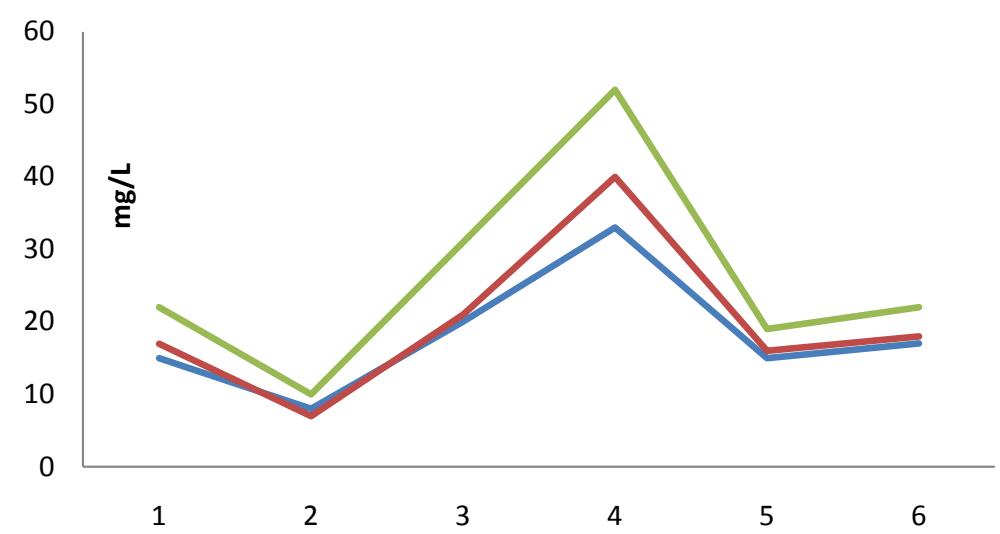

Figure 4. Alkalinity average (three sampling per year) in 1998 (1), 1999 (2), 2011 (3), 2012 (4), 2013 (5), 2014 (6).

\section{Sulfates}

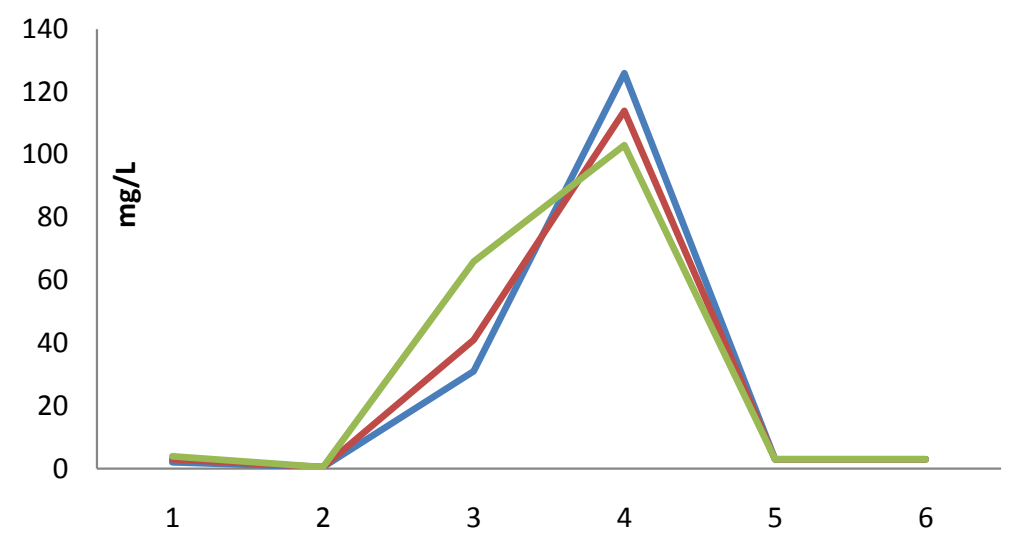

Figure 5. Sulfates average (three sampling per year) in 1998 (1), 1999 (2), 2011 (3), 2012 (4), 2013 (5), 2014 (6).

\section{Hardness}

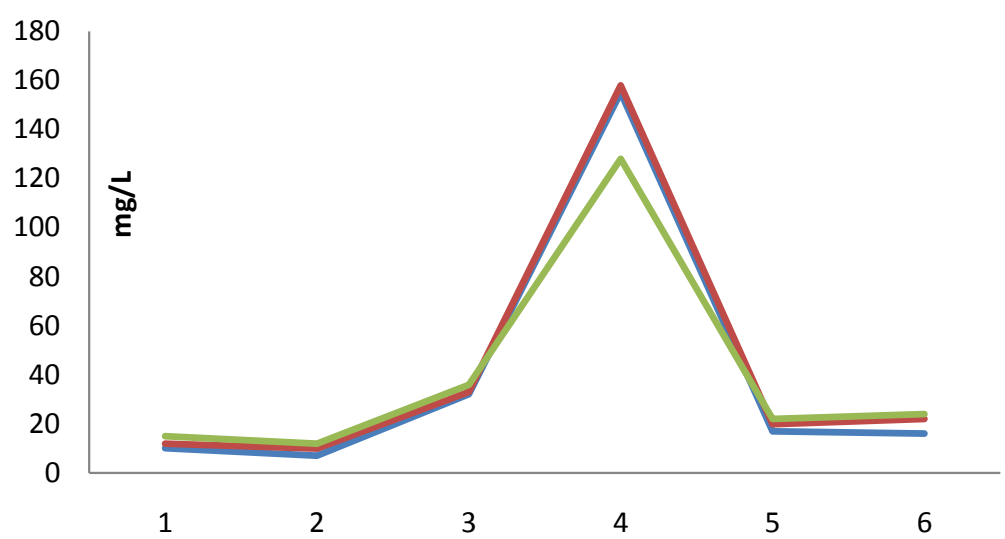

Figure 6. Hardness average (three sampling per year) in 1998 (1), 1999 (2), 2011 (3), 2012 (4), 2013 (5), 2014 (6). 
Table 1. Maximum and minimum values recorded.

\begin{tabular}{ccc}
\hline Measured Parameters & Maximum Value & Minimum Value \\
\hline Alkalinity $(\mathrm{mg} / \mathrm{L})$ & 52 & 7 \\
Chlorides $(\mathrm{mg} / \mathrm{L})$ & 315 & 4 \\
Conductivity (us/cm) & 1457 & 39 \\
Hardness (mg/L) & 158 & 7 \\
Sulfates $(\mathrm{mg} / \mathrm{L})$ & 126 & 0,5 \\
\hline
\end{tabular}

modest laboratory. The work group has determined other parameters but they are not reported because they are very variable by hydrolysis and sensitive to the variations of dissolved oxygen. Dissolved oxygen makes the same environment into oxidizer or reducer depending on whether the riverbed is normal or not. When the river overflows due to the presence of heavy and persistent rains, it floods large areas with abundant vegetation, causing a decrease of dissolved oxygen.

Annual variation of conductivity, chlorides, alkalinity, sulfates and hardness along the Corriente River are given in Figures 2-6. And maximums an minimum values are showed in Table 1.

The negative correlation between the quantified values of the selected parameters and the annual rainfall values is evident. This is due to the effect of dilution caused by a greater amount of precipitation, increasing the flow of the river under study. And a greater concentration of the parameters is evidenced by decreasing the flow of the river due to drier climates and with less precipitation.

The conductivity expresses the ability of a solution to carry electrical current. Conductivity and hardness give information about the concentration of dissolved salts. This ability depends on the presence of ions and its total concentration, mobility, valence and relative concentrations and temperature measurement. When it is higher ion concentration, it is greater conductivity, so conductivity is directly relational with salinity.

Alkalinity is mainly due to the carbonates and bicarbonates present in the river water, and less so due to borates, phosphates and silicates, which may be present.

The hardness is given by various salts of varying composition, mainly due to the presence of calcium and magnesium salts.

\section{Conclusions}

It can be said that low rainfall causes the highest concentration of constituents in the rivers, by increasing all values of the parameters measured during this period. Following the same reasoning, the highest rainfall observed in previous and subsequent years to 2012 generated a decrease in the values obtained by dilution effect.

These abrupt changes in the concentrations of ions were exposed in sections of Results and Discussion. This variation is a result of natural changes and not by (antrophical) man-made phenomena taking into account the very low activity or influence of the industries or agricultural activity surrounding. Therefore, this paper evidences the con- 
stitution of the Corriente River, based on their majority components. This information is established as a historical reference for future environmental assessments that involve this water resource of Corrientes Province, Argentina, and will be useful for future studies about probably macroscopic changes in the natural composition of Corriente River.

\section{References}

[1] Dang, T., Tsujimura, M., Le, V., Kawachi, A. and Thu, D. (2014) Chemical Characteristics of Surface Water and Groundwater in Coastal Watershed, Mekong Delta, Vietnam. Procedia Environmental Sciences, 20, 712-721. https://doi.org/10.1016/j.proenv.2014.03.085

[2] Campodonico, V.A., García, M.G. and Pasquini, A.I. (2015) The Dissolved Chemical and Isotopic Signature Downflow the Confluence of Two Large Rivers: The Case of the Parana and Paraguay Rivers. Journal of Hydrology, 528, 161-176.

https://doi.org/10.1016/j.jhydrol.2015.06.027

[3] Zabala, M.E., Martínez, S., Manzano, M. and Vives, L. (2016) Groundwater Chemical Baseline Values to Assess the Recovery Plan in the Matanza-Riachuelo River Basin, Argentina. Science of the Total Environment, 541, 1516-1530.

https://doi.org/10.1016/j.scitotenv.2015.10.006

[4] Framiñan, M.B. and Brown, O.B. (1996) Study of the Rio de la Plata Turbidity Front. Part I: Spatial and Temporal Distribution. Continental Shelf Research, 16, 1259-1282.

https://doi.org/10.1016/0278-4343(95)00071-2

[5] Butiuc-Keul, A., Momeu, L., Craciunas, C., Dobrota, C., Cuna, S. and Balas, G. (2012) Physico-Chemical and Biological Studies on Water from Aries River (Romania). Journal of Environmental Management, 95, S3-S8. https://doi.org/10.1016/j.jenvman.2011.04.017

[6] Islam, M., Azad, A.K., Ara, M.H. and Rahman, M. (2016) Environmental Study on a Coastal River of Bangladesh with Reference to Irrigation Water Quality Assessment: A Case Study on Shailmari River, Khulna. Journal of Geoscience and Environment Protection, 4, 41-64. https://doi.org/10.4236/gep.2016.410003

[7] Wang, H., Yao, J. and Li, Y. (2016) An Analysis of Water Environment Factors and an Evaluation of Water Quantity of Liangzi Lake. Journal of Geoscience and Environment Protection, 4, 44-51. https://doi.org/10.4236/gep.2016.47006

[8] Wunderlin, D.A., Díaz, M.P., Amé, M.V., Pesce, S.F., Hued, A.C. and Bistoni, M.A. (2001) Pattern Recognition Techniques for the Evaluation of Spatial and Temporal Variations in Water Quality. A Case Study: Córdoba-Argentina, Suquía River Basin. Water Research, 35, 2881-2894. https://doi.org/10.1016/S0043-1354(00)00592-3

[9] Lupi, L., Miglioranza, K.S.B., Aparicio, V.C., Marino, D., Bedmar, F. and Wunderlin, D.A. (2015) Science of the Total Environment Occurrence of Glyphosate and AMPA in an Agricultural Watershed from the Southeastern Region of Argentina. Science of the Total Environment, 536, 687-694. https://doi.org/10.1016/j.scitotenv.2015.07.090

[10] Ruiz Diaz, J.D., Fechner, D.C., Moresi, A.L. and Vazquez, F.A. (2010) DBO5 y otros parámetros físico-químicos como indicadores de contaminación. Río Paraná, costa Corrientes. Journal of FACENA, 26, 3-14.

[11] López, M.A., Acevedo, H.A. and Vazquez, F.A. (2000) Water Quality of the Paraná River at Corrientes, Argentina: A Ten Year Record. Journal of Environmental Hydrology, 8, Paper 9.

[12] Pellerano, R.G., Lezcano, C.A., Marchevsky, E.J. and Vazquez, F.A. (2002) A Physical- 
Chemical Characterization of the Miriñay River, Argentina. Journal of Environmental Hydrology, 10, Paper 4.

[13] APHA, AWWA and WPCF (1989) Standard Methods for the Examination of Water and Wastewater. 17th Edition, Washington DC.

Submit or recommend next manuscript to SCIRP and we will provide best service for you:

Accepting pre-submission inquiries through Email, Facebook, LinkedIn, Twitter, etc. A wide selection of journals (inclusive of 9 subjects, more than 200 journals)

Providing 24-hour high-quality service

User-friendly online submission system

Fair and swift peer-review system

Efficient typesetting and proofreading procedure

Display of the result of downloads and visits, as well as the number of cited articles Maximum dissemination of your research work

Submit your manuscript at: http://papersubmission.scirp.org/

Or contact gep@scirp.org 